\title{
PERANCANGAN APLIKASI GAME OLAHRAGA TRADISIONAL UNTUK ANAK SEKOLAH DASAR MENGGUNAKAN MACROMEDIA FLASH
}

\author{
Rizka Tri Alinse ${ }^{1}$, Toibah Umi Kalsum ${ }^{2}$ \\ 1,2 DosenTetap Program Studi Informatika Fakultas Ilmu Komputer Universitas Dehasen Bengkulu \\ Jl. Meranti Raya No. 32 Kota Bengkulu 38228 Telp. (0736) 22027, 26957 Fax. (0736) 341139) \\ e-mail: rizkatri07@gmail.com, cici.umie@gmail.com
}

\begin{abstract}
Traditional sports games can be used to introduce elementary school students to better understand how to identify the origins of the game and the game itself. So the traditional games, especially traditional sports games will be maintained and remain known in the community. The purpose of this study was to design a traditional sports game application for primary school children using Macromedia Flash 8. The method used in this research is the development of systems that implement the design into a form design application of traditional sports games for primary school children. With the application of this traditional sport games elementary school students can get to know and understand what and how traditional sports long jump game was played. The application of this traditional sport games can be developed from the design and also from the function.

Keywords: Game, Olahraga, Lompat Jauh
\end{abstract}

Intisari-Game olahraga tradisional dapat digunakan untuk mengenalkan kepada siswa Sekolah Dasar untuk lebih memahami cara permainan serta mengenali asal usul game itu sendiri. Sehingga $\neg$ game tradisional khususnya game olahraga tradisional akan terpelihara dan tetap dikenal di masyarakat. Tujuan penelitian ini adalah untuk merancang aplikasi game olahraga tradisional untuk anak Sekolah Dasar menggunakan Macromedia Flash 8. Metode yang digunakan dalam penelitian ini adalah metode pengembangan sistem yaitu mengimplementasi rancangan ke dalam sebuah bentuk desain aplikasi game olahraga tradisional untuk anak sekolah dasar. Dengan aplikasi game olahraga tradisional ini siswa sekolah dasar dapat lebih mengenal dan memahami apa dan bagaimana game olahraga tradisional lompat jauh itu dimainkan. Aplikasi game olahraga tradisional ini dapat dikembangkan lagi dari sisi desain dan juga dari sisi fungsi.

Kata Kunci: Game, Olahraga, Lompat Jauh

\section{PENDAhULUAN}

Dewasa ini perkembangan teknologi game semakin cepat, hal ini menjadikan persaingan antar perusahaan pembuat game untuk melakukan berbagai macam inovasi dalam game tidak terkecuali di Indonesia. Game saat ini sudah menjadi alternatif hiburan bagi masyarakat baik tua, muda, pria maupun wanita ataupun anak-anak. Industri dan bisnis pengembangan game juga sudah menjadi suatu hal yang menjanjikan, terbukti dengan banyaknya perusahaan pengembang game di Amerika, Eropa, dan Asia.

Anak-anak merupakan penikmat game yang sangat banyak, khususnya anak-anak tingkat Sekolah Dasar. Untuk itu perlu adanya game yang mendidik, serta mampu mengenalkan game tradisional yang merupakan produk budaya bangsa Indonesia khususnya game olahraga tradisional.

Game olahraga tradisional dapat digunakan untuk mengenalkan kepada siswa Sekolah Dasar untuk lebih memahami cara permainan serta mengenali asal usul game itu sendiri. Sehingga game tradisional khususnya game olahraga tradisional akan terpelihara dan tetap dikenal di masyarakat..

\section{TINJAUAN PUSTAKA}

A. Game

Dalam sebuah game ada beberapa komponen yang ada, misalnya jenis game, karakter, background, suara, gerakan atau bahkan movie. Semua komponen tersebut sangat penting dalam pembuatan game, sehingga kalau kita membuat setiap komponen menarik, maka tentu saja game yang kita buat akan menarik dan tidak membosankan.

\section{B. Olahraga}

Olahraga adalah suatu bentuk aktivitas fisik yang terencana dan terstruktur yang melibatkan gerakan tubuh berulang-ulang dan ditujukan untuk meningkatkan kebugaran jasmani. Kesehatan 
olahraga adalah upaya kesehatan yang memanfaatkan olahraga untuk meningkatkan derajat kesehatan. Olahraga merupakan sebagian kebutuhan pokok dalam kehidupan sehari-hari karena dapat meningkatkan kebugaran yang diperlukan dalam melakukan tugasnya. Olahraga dapat dimulai sejak usia muda hingga usia lanjut dan dapat dilakukan setiap hari.

\section{Lompat Jauh}

Lompat jauh merupakan bagian dari cabang atletik. Dari beberapa gaya yang terdapat pada lompat jauh, seperti gaya jongkok, gaya menggantung, dan gaya jalan diudara, gaya yang paling mudah dilakukan adalah gaya jongkok. Karena itu, gaya ini biasanya sering dipakai oleh pelompat jauh pemula. Tahap-tahap lompat jauh yang harus dikuasai adalah awalan, tolakan, melayang, dan mendarat

Berikut ini latihan-latihan pendukung yang bisa kamu lakukan agar tahap-tahap lompat jauh di atas dapat kamu kuasai. Latihan itu antara lain:

\section{A. Latihan melompat tanpa diawali awalan}

Cara melakukannya:

1. Sikap awal berdiri tegak.

2. Tolakkan kedua kakimu sehingga badanmu melompat ke depan sejauh-jauhnya.

3. Kemudian, mendarat dengan menggunakan kedua kaki.

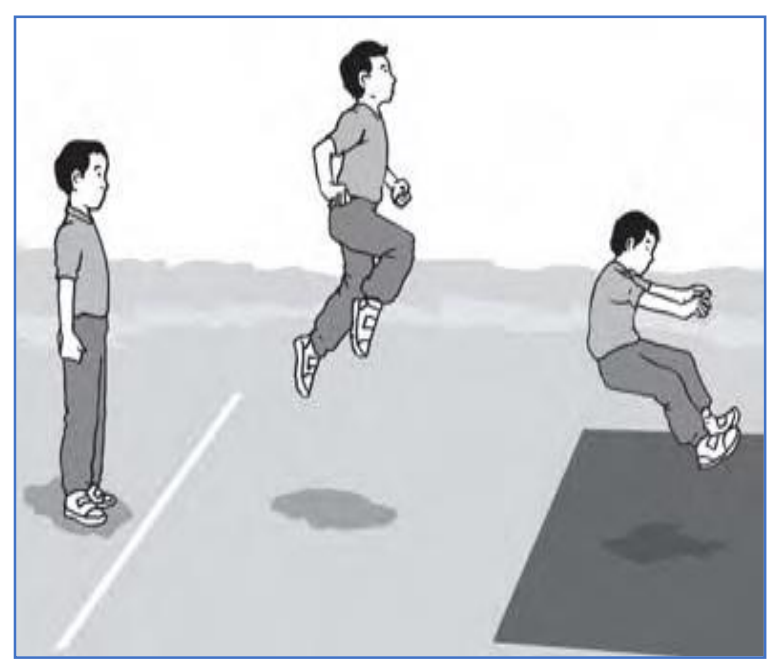

Gambar 1. Melompat Jauh Tanpa Diawali Dengan

\section{Awalan}

B. Latihan melompat diawali dengan awalan Cara melakukannya:

1. Sikap awal berdiri tegak dengan jarak dari papan tolakan sekitar 4 meter.

2. Bersiaplah lari menuju papan loncatan.

3. Lakukan tolakan pada papan loncatan menggunakan salah satu kakimu.

4. Kemudian mendarat dengan menggunakan kedua kaki.

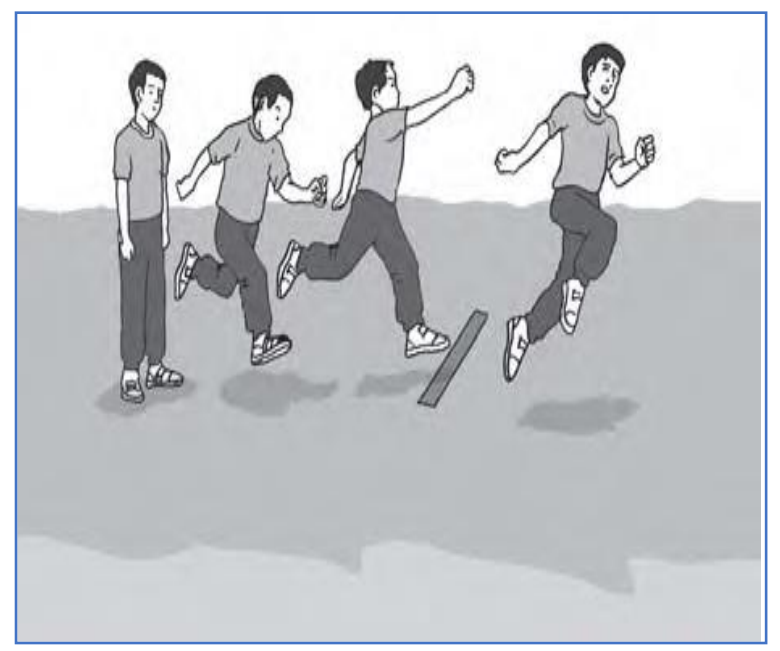

Gambar 2. Latihan Melompat Jauh Diawali Dengan

\section{Awalan}

\section{Lapangan Lompat Jauh}

Berikut adalah ukuran lapangan lompat jauh:

- Panjang bak pasir untuk tempat mendarat: $9 \mathrm{~m}$ 
* Lebar bak pasir: 2,75 m

* Jarak papan tolak dengan bak pasir: $1 \mathrm{~m}$

* Panjang lintasan untuk awalan: $45 \mathrm{~m}$

* Papan tumpuan/tolakan: tebal $10 \mathrm{~cm}$, panjang $172 \mathrm{~cm}$, lebar $30 \mathrm{~cm}$.

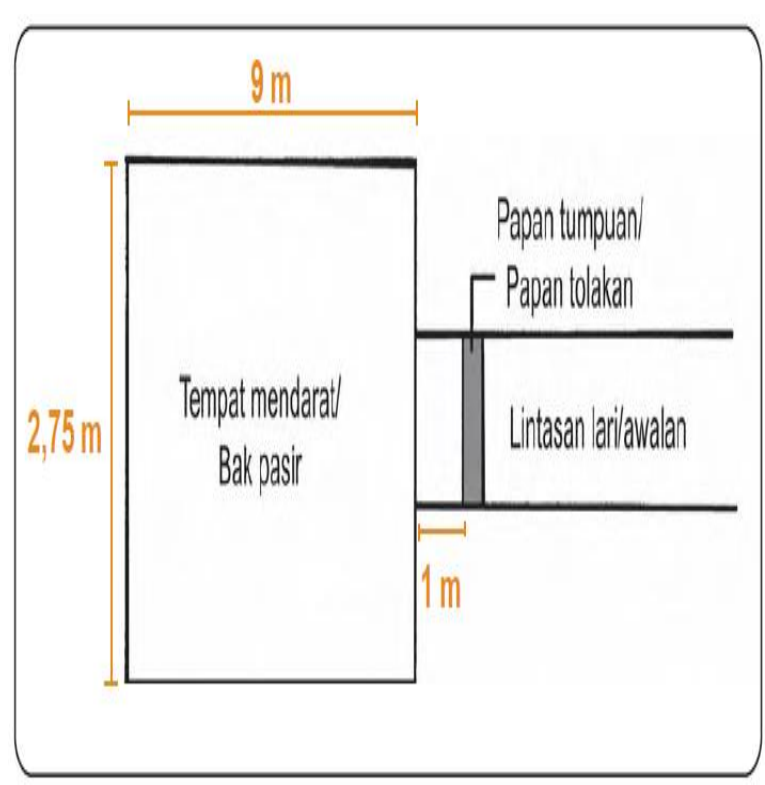

Gambar Error! No text of specified style in

document.. Lapangan lompat jauh.

\section{III.Metode Penelitian}

Metode yang digunakan dalam penelitian ini adalah metode pengembangan sistem dengan tujuan meningkatkan dan mengefektifkan sistem yang sudah ada. Dengan langkah yang dilakukan dalam sistem baru ini yaitu dengan cara melakukan analisis kebutuhan data, mengumpulkan data, merancang dengan menggunakan pemodelan terstruktur, mengimplementasi rancangan ke dalam sebuah bentuk desain aplikasi game olahraga tradisional untuk anak sekolah dasar.

\section{IV.HASIL DN PEMBAHASAAN}

A. Hasil Rancangan Program

Sesuai dengan rancangan program pada bab sebelumnya, pada bab ini dibuat aplikasi game olahraga tradisional untuk anak Sekolah Dasar menggunakan Macromedia Flash. Adapun tampilan dan pembahasan program sebagai berikut :

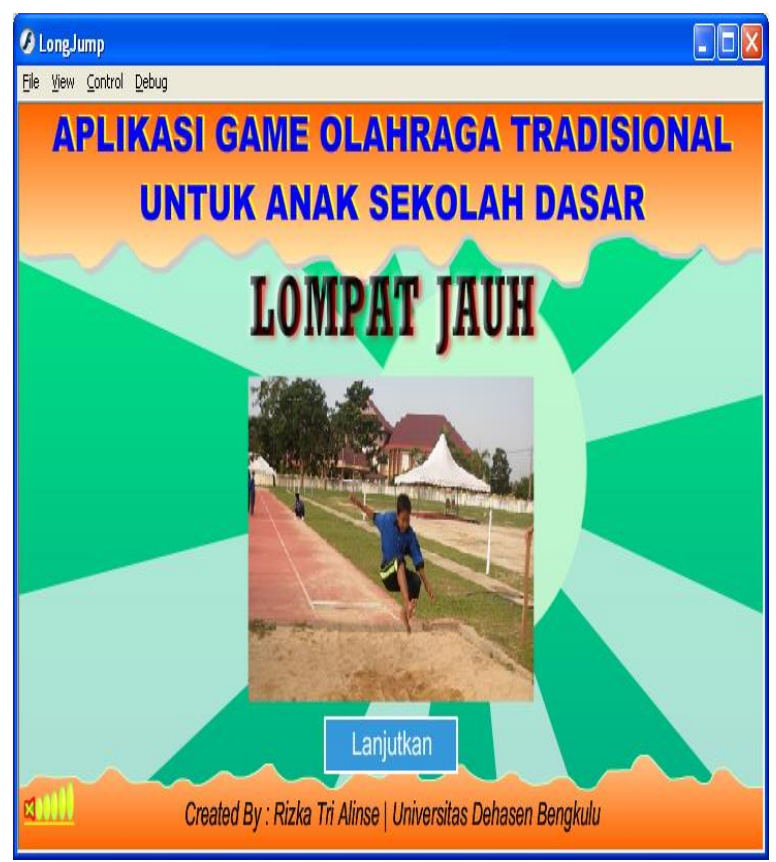

\section{Gambar 4. Menu Pembuka}

Menu pembuka pada aplikasi game ini manampilkan judul aplikasi, nama game dan animasi pengantar game. Terdapat tombol lanjutkan untuk menuju ke menu utama aplikasi game ini. Selain itu juga terdapat sound control untuk mengontrol iringan lagu pada game dan informasi pembuat aplikasi. 


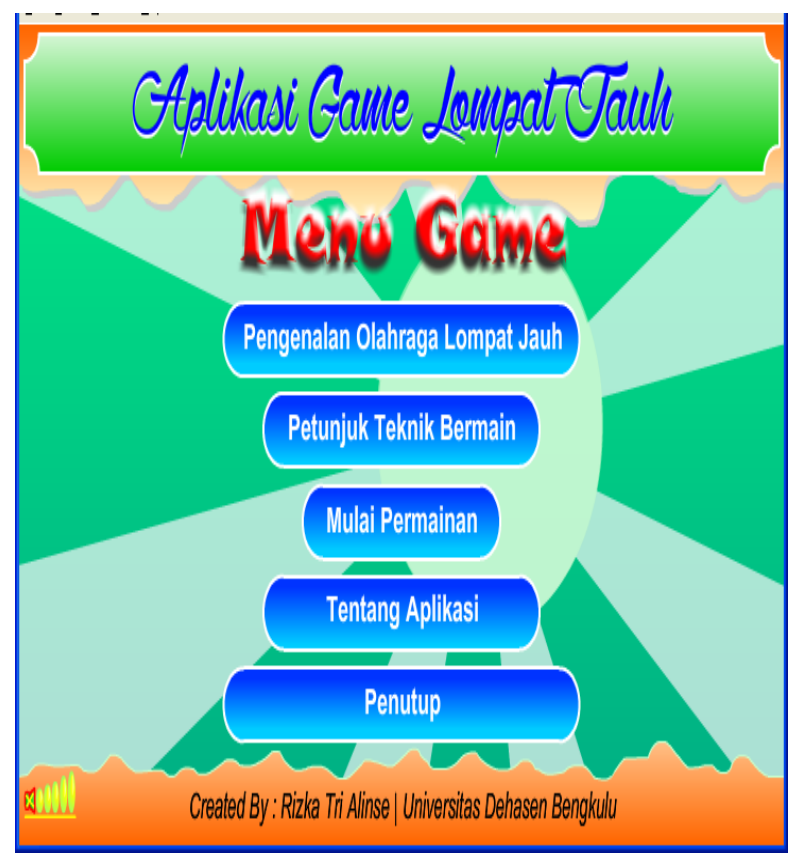

Gambar 5. Menu Utama

Menu utama aplikasi game ini menampilkan judul game dan beberapa tombol diantaranya: tombol pengenalan olahraga lompat jauh, petunjuk teknik bermain, mulai permainan, tentang aplikasi dan tombol penutup.

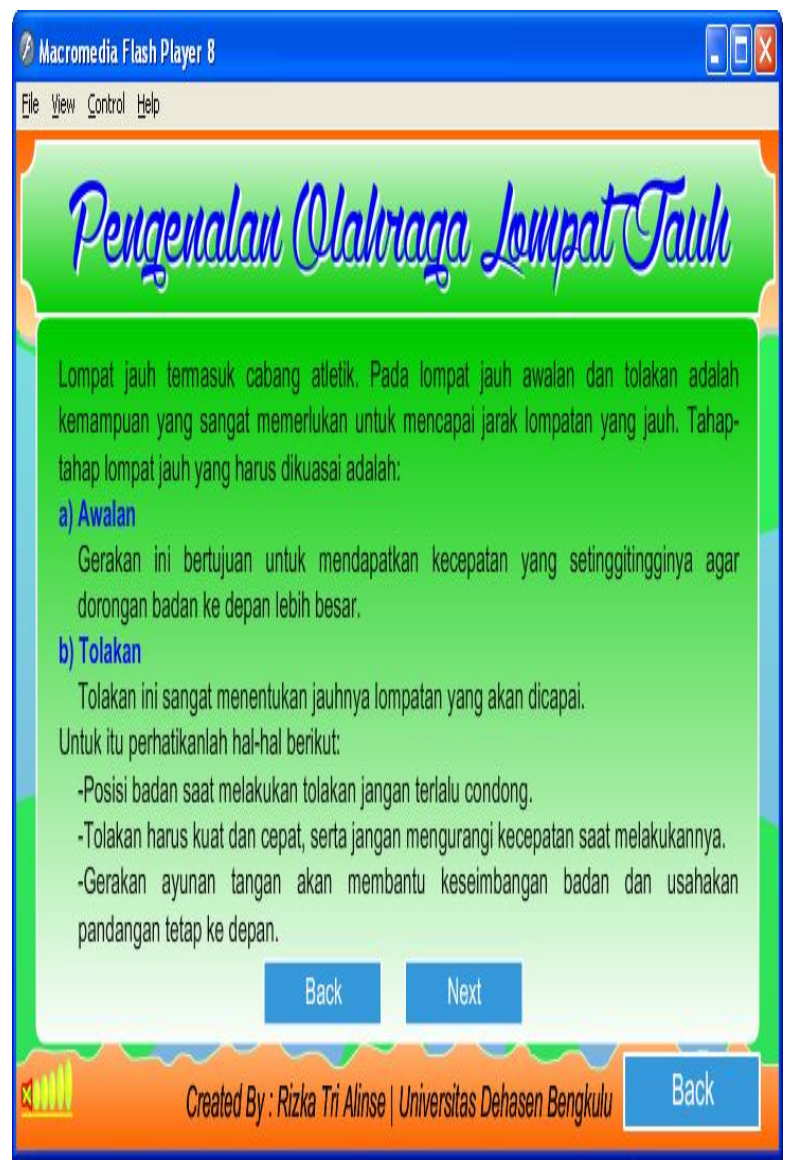

Gambar 6. Menu Pengenalan Olahraga Lompat Jauh

Menu ini menampilkan teks tentang olahraga lompat jauh, terdapat tombol next dan back untuk mengontrol penampilan materi. Terdapat juga tombol back untuk kembali ke menu utama, dan sound control untuk mengontrol lagu pengiring. 


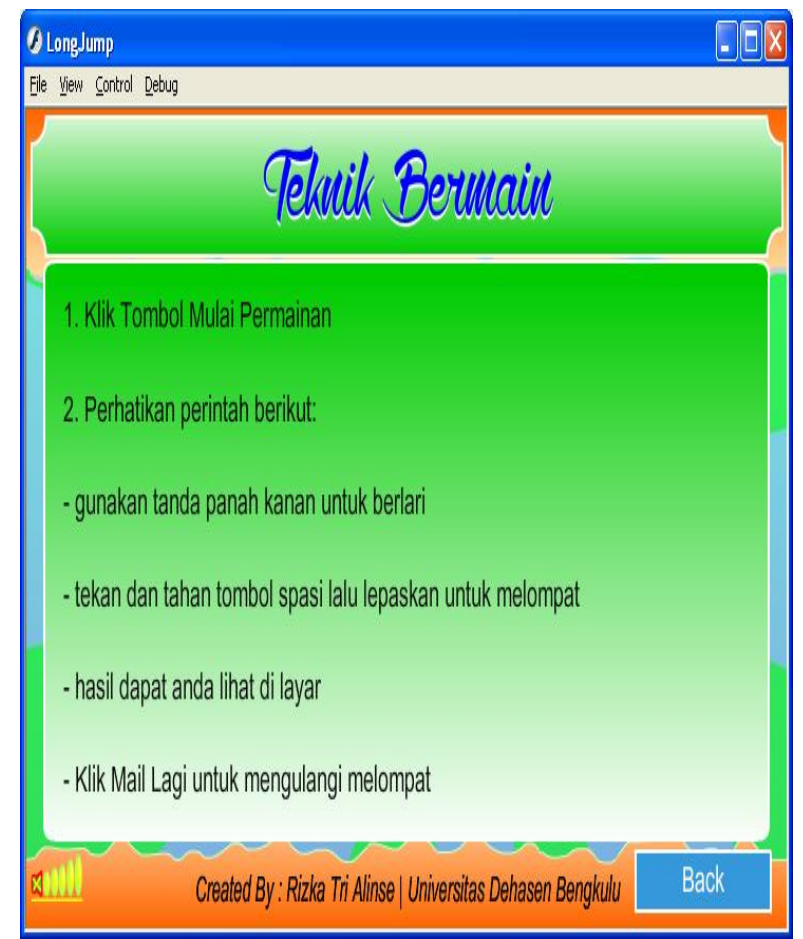

Gambar 7. Menu Petunjuk Teknik Bermain

Pada menu petunjuk teknik bermain terdapat informasi tentang penggunaan tombol dan mouse dalam bermain game lompat jauh pada aplikasi ini. Terdapat juga tombol back untuk kembali ke menu utama.

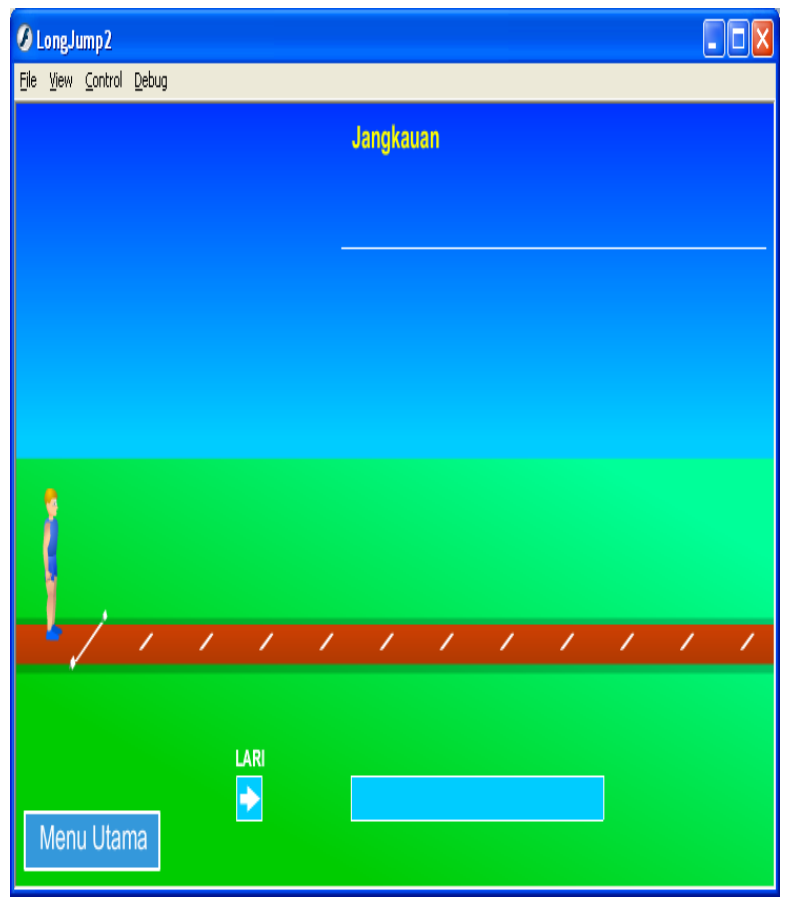

Gambar 8. Menu Permainan

Menu ini ditampilkan dengan menekan tombol mulai permainan pada menu utama. Untuk memainkan game siswa dapat menekan tombol panah kanan untuk mambuat atlet berlari. Semakin cepat kita menekan tombol panah kanan maka akan semakin kencang pula atlet pada game berlari. Kemudian untuk melompat menggunakan tombol spasi. Jarak lompatan akan ditampilkan dalam satuan meter, dan jika atlet melewati batas papan tumpuan maka dianggap gagal. 


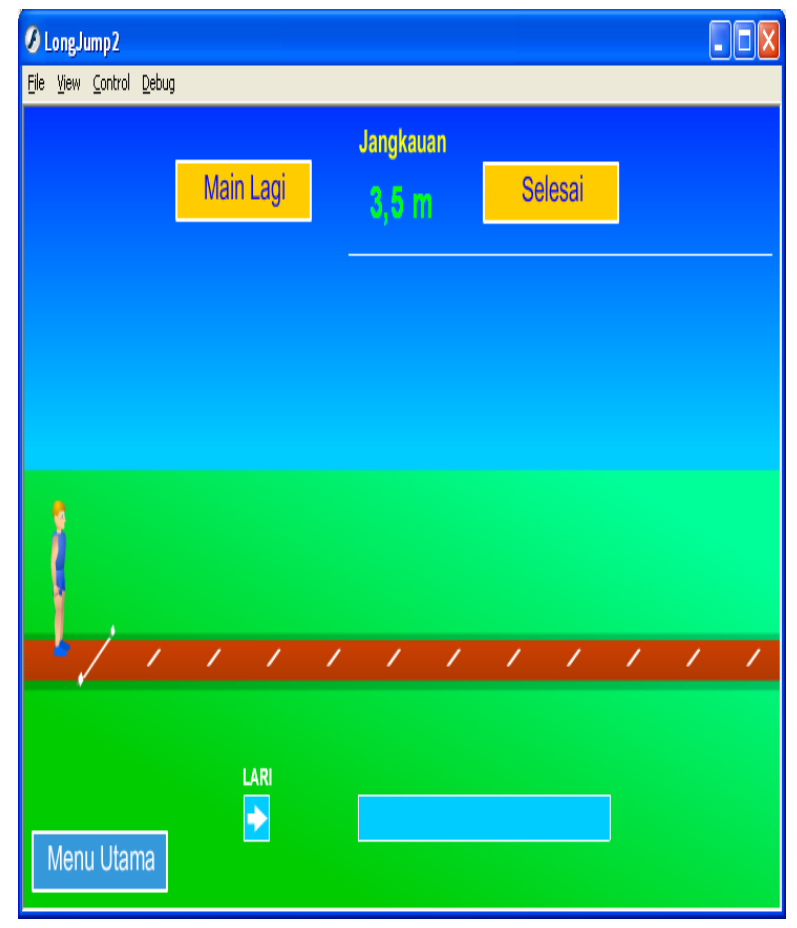

Gambar 9. Tampilan Hasil Permainan

Hasil permainan muncul ketika atlet sudah melompat, pada bagian jangkauan akan menampilkan informasi berapa meter atlet dapat melompat, tentunya sesuai dengan pemain / pengguna aplikasi ini. Untuk bermain lagi dapat di klik pada tombol Main Lagi. Dan untuk mengakhiri permainan dapat di klik tombol Selesai.

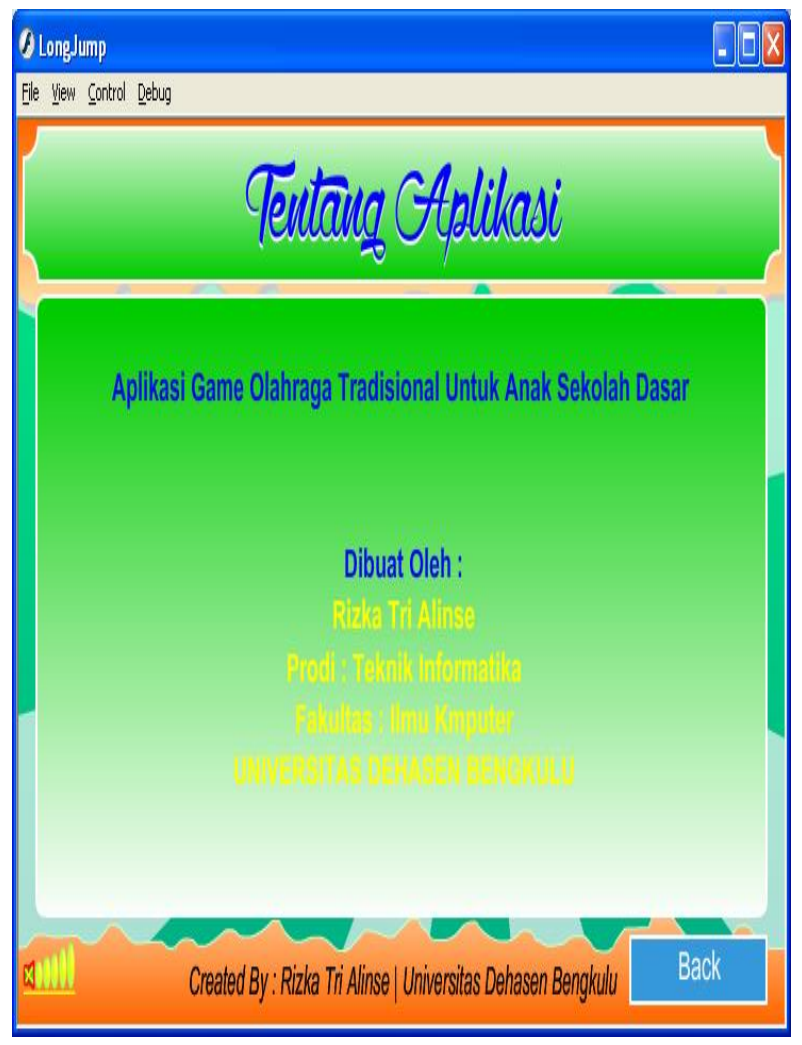

Gambar 9. Menu Tentang Aplikasi

Pada menu ini ditampilkan informasi tentang aplikasi, yaitu judul aplikasi dan informasi biodata pembuat aplikasi (penulis).

\section{KESIMPULAN}

Berdasarkan hasil penelitian dan pembahasan dapat ditarik kesimpulan: Macromedia flash 8 dapat digunakan untuk membuat aplikasi game olahraga tradisional khususnya lompat jauh. Dengan aplikasi game olahraga tradisional ini siswa sekolah dasar dapat lebih mengenal dan memahami apa dan bagaimana game olahraga tradisional lompat jauh itu dimainkan. Dari hasil pengujian sistem aplikasi game tradisional untuk anak sekolah dasar ini layak untuk digunakan.

\section{DAFTAR PUSTAKA}

[1] Amin, M. M. (2016). Implementasi Kriptografi Klasik Pada Komunikasi Berbasis Teks. Pseudocode, 3(2), 129-136.

[2] Raharjo, W. S., \& Sutanti, D. (2015).Implementasi Zero Knowledge Proof Menggunakan Protokol Feige Fiat Shamir Untuk Verifikasi Tiket 
Rahasia. Ultimatics: Jurnal Teknik Informatika, 7(2), 91-97.

[3] Permana, A. A., \& Nurnaningsih, D. (2018). Rancangan Aplikasi Pengamanan Data Dengan Algoritma Advanced Encyption Standard (Aes). JURNAL TEKNIK INFORMATIKA, 11(2), $177-186$

[4] Zelvina, A., Effendi, S., \& Arisandi, D. (2012). Perancangan Aplikasi Pembelajaran Kriptografi Kunci Publik ElGamal Untuk Mahasiswa. Dunia Teknologi Informasi-Jurnal Online, 1(1).

[5] Pabokory, F. N., Astuti, I. F., \& Kridalaksana, A. H. (2016). Implementasi Kriptografi Pengamanan Data Pada Pesan Teks, Isi File Dokumen, Dan File Dokumen Menggunakan Algoritma Advanced Encryption Standard. Informatika Mulawarman: Jurnal Ilmiah Ilmu Komputer, 10(1), 20-31.

[6] Putro, H. P. Percobaan Pemanfaatan Graf pada Protokol Kriptografi. Program Studi Teknik Informatika STEI ITB, Bandung, 40135.

[7] Panjaitan, C. (2019). Analisis Pola Identifikasi Zero Knowledge Proof dengan Algoritma Feige Fiat Shamir, Guillou Quisquater dan Schnorr pada Sistem Keamanan Informasi. 